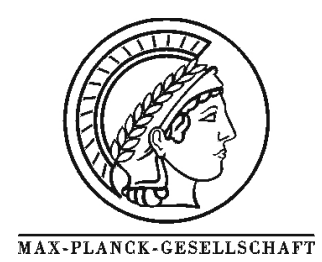

Journal of Physics and Chemistry of Solids, 65 (2004) 2-3, 413-420

\title{
Intercalation of $\left[\mathrm{Pt}\left(\mathrm{NH}_{3}\right)_{4}\right]^{2+}$ ions into layered sodium silicate magadiite: A useful method to enhance their stabilisation in a highly dispersed state
}

\author{
W. Schwieger ${ }^{1, *}$, T. Selvam ${ }^{1}$, O. Gravenhorst ${ }^{1}$, N. Pfänder ${ }^{2}$, R. Schlögl', G. T. P. Mabande ${ }^{1}$ \\ ${ }^{1}$ Institute of Technical Chemistry I, University of Erlangen-Nuremberg, D-91058 Erlangen, Germany \\ ${ }^{2}$ Department of Inorganic Chemistry, Fritz-Haber-Institute of the MPG, Faradayweg 4-6, 14195 Berlin, Germany \\ * Corresponding author: e-mail wilhelm.schwieger@rzmail.uni-erlangen.de, fax +49-9131-852 7421
}

Accepted 19 August 2003

\begin{abstract}
Al-free layered sodium silicate magadiite has been used as the host material for the stabilisation of $\left[\mathrm{Pt}\left(\mathrm{NH}_{3}\right)_{4}\right]^{2+}$ ions via intercalation and/or ionexchange reactions. The stabilisation of $\left.\mathrm{Pt}\left(\mathrm{NH}_{3}\right)_{4}\right]^{2+}$ ions in between the layers of Na-magadiite was confirmed by thermogravimetric analysis (TGA), where increased decomposition temperatures were observed for the intercalated materials. The intercalation behaviour of Na-magadiite was evident from the significant uptake of Pt ions (22.2 wt.\%). When silica gel was used as the host matrix, negligible uptake of Pt ions (1.3 wt.\%) was noticed. The X-ray diffraction (XRD) measurements revealed no appreciable change in the basal spacing of the intercalated materials. Nevertheless, the decrease in the intensity of the 001 peak with increasing Pt loadings (from 13.0 to $22.2 \mathrm{wt} . \%$ ) substantiated the intercalation of $\left[\mathrm{Pt}\left(\mathrm{NH}_{3}\right)_{4}\right]^{2+}$ ions within the interlayer spaces of Na-magadiite. The transmission electron microscopy (TEM) studies of the intercalated materials revealed that $\left[\mathrm{Pt}\left(\mathrm{NH}_{3}\right)_{4}\right]^{2+}$ ions were homogeneously intercalated in the magadiite matrix, ranging from 2-3 nm. Subsequent calcination of the intercalated materials at $600{ }^{\circ} \mathrm{C}$ in air led to the formation of Pt nanoparticles supported on silica. The results of XRD and TEM indicated that Pt nanoparticles were highly dispersed on the silica support and were in the range of 5-12 $\mathrm{nm}$. Moreover, chemical analyses confirmed the high loading of Pt on silica in agreement with the TGA results.
\end{abstract}

Keywords: Na-magadiite, intercalation of $\left[\mathrm{Pt}\left(\mathrm{NH}_{3}\right)_{4}\right]^{2+}$ ions, $\mathrm{Pt}$ nanoparticles

\section{Introduction}

Silica-supported Pt catalysts are of considerable interest because of their potential applications in a large number of industrially important chemical reactions such as oxidation, hydrogenation, cracking, hydroisomerisation and $\mathrm{NO}_{\mathrm{x}}$ reduction reactions [1-4]. For most of these potential catalytic applications, highly dispersed and thermally stable Pt particles or nano-clusters are necessary for the better performance of the catalysts. The most common methods for the preparation of supported Pt catalysts are ion-exchange and impregnation of the host matrix with solutions of the $\mathrm{Pt}$ salt, followed by calcination and reduction, using supports such as silica, alumina, microporous and mesoporous materials [5-8]. In particular, the sol-gel method is an important method for the preparation of silica-supported Pt catalysts with high BET surface areas [9, 10]. This method offers significant advantages, including high purity, chemical homogeneity and controlled particle size. However, one of the major disadvantages of the sol-gel method is the high cost of the alkoxide reagents. Recently, the preparation of $\mathrm{Pt} / \mathrm{SiO}_{2}$ ultra fine particles in reverse micelles has been communicated by Miyao et al [11]. The synthesis of Pt complexes hosted in microporous and mesoporous materials via the 'ship-in-bottle' method has also been reported by Fukuoka et al. [12]. Furthermore, the hydrothermal synthesis of $\mathrm{Pt}$ containing mesoporous silica's, e.g. MSU-1 [13] and MCM41 [14], has received considerable attention because of their unique catalytic properties. Although this method allows the preparation of highly dispersed and thermally stable $\mathrm{Pt}$ nanoparticles on the silica-support materials with controlled 
pore dimensions and high BET surface areas, the Pt loadings are quite low (1-6 wt.\%). Therefore, the development of alternative approaches that allow for the preparation of highly loaded Pt nanoparticles supported on silica would be of great interest.

Na-magadiite $\left(\mathrm{Na}_{2} \mathrm{Si}_{14} \mathrm{O}_{29} \cdot \mathrm{nH}_{2} \mathrm{O}\right)$ is one of the most important aluminium-free layered silicates. The exact crystal structure of Na-magadiite is not known. However, on the basis of various structural characterization techniques, three possible structures have been proposed [15]. In addition, the layered character and the swelling behaviour of $\mathrm{Na}$ magadiite are well documented in the literature [10-14]. It is well known that the layers of $\mathrm{Na}$-magadiite can be expanded by appropriate treatment by intercalation of guest molecules in between the layers of Na-magadiite. A wide variety of intercalation compounds such as alkylammonium-magadiite [16], ethylene glycol-magadiite [17], $\mathrm{Co}(\mathrm{sep})^{3+}$-magadiite [18] and $\mathrm{Eu}^{3+}$-magadiite [19] have been reported. The interlayer spaces of Na-magadiite $(1.0 \mathrm{~nm})$ have been fruitfully exploited in developing organic-inorganic nanocomposites by intercalating organochlorosilanes [20]. Recently, it has been reported that Na-magadiite is an excellent host matrix for the preparation polymer-inorganic nanocomposites [21]. Photofunctional-magadiite materials, such as tris(2,2'bipyridine)ruthenium(II)-magadiite [22] and azobenzenemagadiite [23], are currently under increased investigation for the high potential they offer for various technological applications. In addition, Na-magadiite has been widely used as a precursor in the preparation of microporous materials such as MFI, MEL, FER and MOR [24].

The intercalation of $\left[\mathrm{Pt}(\mathrm{en})_{2}\right]^{2+}$ and $\left[\mathrm{PtCl}_{2}(\mathrm{en})_{2}\right]^{2+}$ ions into clay minerals, Na-montmorillonite, has been reported by Kijima et al. [25]. Although clay minerals, such as montmorillonite [26] and smectite [27], have been used as hosts for the preparation of transition metal nanoparticles, the use of clay minerals imposes some rather serious limitations. For instance, clay minerals possess hydrolytic instability in acidic and basic conditions; and very low ionexchange capacity. However, the use of aluminium-free layered sodium silicates would circumvent the problems of hydrolytic instability and very low ion-exchange capacity etc., associated with the clay minerals. Up until now, much less attention has been paid to exploit the unique nature of the nanoscopic interlayer spaces of aluminium-free layered sodium silicate for the preparation of silica-supported $\mathrm{Pt}$ nanoparticles. In an earlier study, we prepared $\left[\mathrm{Pt}\left(\mathrm{NH}_{3}\right)_{4}\right]^{2+}$. ilerite by intercalation of Na-ilerite with $\left[\mathrm{Pt}\left(\mathrm{NH}_{3}\right)_{4}\right]^{2+}$ ions at room temperature [28]. Subsequent calcination of the intercalated product (at $380{ }^{\circ} \mathrm{C}$ ) led to the formation of highly dispersed Pt nanoparticles supported on silica. This method is particularly attractive for the preparation of highly loaded Pt nanoparticles (20.0 wt.\%) supported on silica. To our knowledge, such high loading of platinum nanoparticles (2-5 $\mathrm{nm}$ ) in a highly dispersed state has not been achieved on the traditional supports such as silica, alumina, microporous and mesoporous materials.

In continuation of our previous work, herein, we report the preparation of highly loaded Pt nanoparticles in a highly dispersed state on silica by intercalation of $\left[\mathrm{Pt}\left(\mathrm{NH}_{3}\right)_{4}\right]^{2+}$ ions into Na-magadiite. The potential advantages of the use of Na-magadiite as a host for the preparation of silica-supported $\mathrm{Pt}$ nanoparticles are its higher cation exchange capacity (1.8 mequiv/g) and thermal stability (500-600 $\left.{ }^{\circ} \mathrm{C}\right)$. A series of silica-supported Pt nanoparticles catalysts with different Pt (13.0-22.2 wt.\%) contents have been prepared using Na-magadiite as the host matrix and studied by TGA, XRD, TEM and ICP measurements.

\section{Experimental}

\subsection{Synthesis of Na-magadiite}

Na-magadiite was synthesised hydrothermally according to the published procedure [29]. The hydrothermal synthesis of Na-magadiite was carried out at $150{ }^{\circ} \mathrm{C}$ with the following molar gel compositions: $5 \mathrm{SiO}_{2}: \mathrm{Na}_{2} \mathrm{O}: 75 \mathrm{H}_{2} \mathrm{O}$. From the chemical and thermogravimetric analysis (TGA), it was found that the chemical composition of the Namagadiite used in this study was $13.8 \mathrm{SiO}_{2}: \mathrm{Na}_{2} \mathrm{O}: 9.8$ $\mathrm{H}_{2} \mathrm{O}$.

\subsection{Intercalation of $\left[\mathrm{Pt}\left(\mathrm{NH}_{3}\right)_{4}\right]^{2+}$ ions into Na-magadiite} Intercalation of $\left[\mathrm{Pt}\left(\mathrm{NH}_{3}\right)_{4}\right]^{2+}$ ions into $\mathrm{Na}$ magadiite was typically performed as follows: First, Namagadiite was suspended in $25 \mathrm{ml}$ of deionised water (A) and sonicated for $30 \mathrm{~min}$. A second solution was prepared by dissolving the required amount of $\left[\mathrm{Pt}\left(\mathrm{NH}_{3}\right)_{4}\right] \mathrm{Cl}_{2}$ in $25 \mathrm{ml}$ of deionised water (B). Then, the solution $\mathrm{B}$ was added into the suspension $\mathrm{A}$ and the final mixture was vigorously stirred at room temperature for $48 \mathrm{~h}$. The $\mathrm{pH}$ of the final mixture was 4.2-4.6. The resulting intercalated product, $\left[\mathrm{Pt}\left(\mathrm{NH}_{3}\right)_{4}\right]^{2+}$-magadiite, was filtered, and then dried at room temperature for $24 \mathrm{~h}$. Three samples with different Pt loadings were prepared by changing the amount of Pt concentration during the intercalation reaction. The molar ratio of $\mathrm{Na}$ ions present in the host matrix, Na-magadiite, to $\mathrm{Pt}$ was $1: 0.25,1: 1$ and $1: 2$, respectively.

In order to prepare the Pt nanoparticles supported on silica, the calcination of the intercalated product, $\left[\mathrm{Pt}\left(\mathrm{NH}_{3}\right)_{4}\right]^{2+}$-magadiite, was carried out in a programmable furnace. The temperature of the furnace was increased from room temperature to $600{ }^{\circ} \mathrm{C}$ at a ramp rate of $5{ }^{\circ} \mathrm{C} \mathrm{min}{ }^{-1}$ in flowing air and maintained at this temperature for $5 \mathrm{~h}$ and then cooled down to room temperature. A schematic representation of the preparation of highly-loaded Pt nanoparticles on silica $\left(\mathrm{Pt} / \mathrm{SiO}_{2}\right)$ by intercalation of $\mathrm{Na}$-magadiite with $\left[\mathrm{Pt}\left(\mathrm{NH}_{3}\right)_{4}\right]^{2+}$ ions followed by calcination of the intercalated product at $600{ }^{\circ} \mathrm{C}$ in air is shown in Fig. 1.

\subsection{Characterisation}

Thermogravimetric analyses (TGA) of the samples were performed on a TG-DTA instrument (SDT 2960, TA Instruments, USA). The measurements were conducted from ambient temperature to $1000{ }^{\circ} \mathrm{C}$ at a heating rate of $10{ }^{\circ} \mathrm{C}$ $\mathrm{min}^{-1}$ in air. The amount of platinum loaded was calculated on the basis of the weight loss of the four $\mathrm{NH}_{3}$ ligands from the $\left[\mathrm{Pt}\left(\mathrm{NH}_{3}\right)_{4}\right]^{2+}$ ions which were intercalated in between the layers of magadiite. Inductively Coupled Plasma Emission 


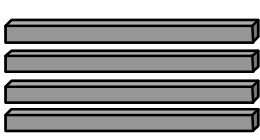

\section{- $\left[\mathrm{Pt}\left(\mathrm{NH}_{3}\right)_{4}\right]^{2+}$ ions intercalation}

$25^{\circ} \mathrm{C}$

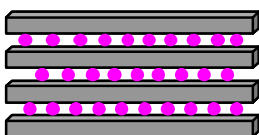

$\left[\mathrm{Pt}\left(\mathrm{NH}_{3}\right)_{4}\right]^{2+}$-magadiite
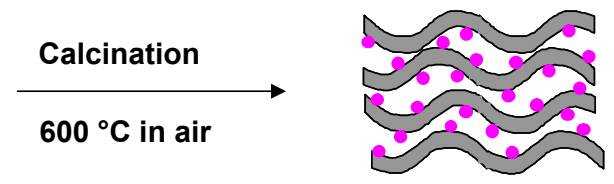

Pt nanoparticles supported on $\mathrm{SiO}_{2}$

Fig. 1. Schematic representation of the preparation of highly-loaded $\mathrm{Pt}$ nanoparticles on silica $\left(\mathrm{Pt} / \mathrm{SiO}_{2}\right)$ by intercalation of Namagadiite with $\left[\mathrm{Pt}\left(\mathrm{NH}_{3}\right)_{4}\right]^{2+}$ ions at room temperature followed by calcination at $600{ }^{\circ} \mathrm{C}$ in air.

analysis (ICP, Perkin-Elmer 400) was also used to determine the platinum loadings.

The X-ray powder diffraction (XRD) measurements were carried out on a Philips X-ray diffractometer using $\mathrm{Cu}-\mathrm{K} \alpha$ radiation. All the samples were scanned in the $2 \theta$ range of $2-70^{\circ}$ at a scan rate of $2^{\circ} \mathrm{min}^{-1}$. The average crystallite size of platinum was calculated from the peak $(2 \theta$ $=39.4^{\circ}$ ) broadening using the Debye-scherrer equation, $\mathrm{D}$ $(\AA)=k \cdot \lambda / b \cdot \operatorname{Cos} \theta$, where $\mathrm{k}$ is the prefactor $(0.9)$ and $\mathrm{b}$ is the full-width at half maximum.

The average sizes of Pt nanoparticles were determined by using a Philips CM 200 transmission electron microscope (TEM) equipped with a $\mathrm{LaB}_{6}$ filament. The microscope was operated at $200 \mathrm{kV}$. The specimens for the TEM studies were prepared by suspending a small amount of the sample in ethanol by ultrasonic treatment. A drop of the ethanol suspension was placed on the carbon coated copper grid and the ethanol was then allowed to evaporate in ambient conditions.

\section{Results and discussion}

\subsection{Thermogravimetric (TGA) and chemical analyses}

Fig. 2 shows the TGA curves for the pure $\left[\mathrm{Pt}\left(\mathrm{NH}_{3}\right)_{4} \mathrm{Cl}_{2}\right]$ complex, Na-magadiite, and the $\left[\mathrm{Pt}\left(\mathrm{NH}_{3}\right)_{4}\right]^{2+}$. magadiite samples with different $\mathrm{Pt}$ loadings which were

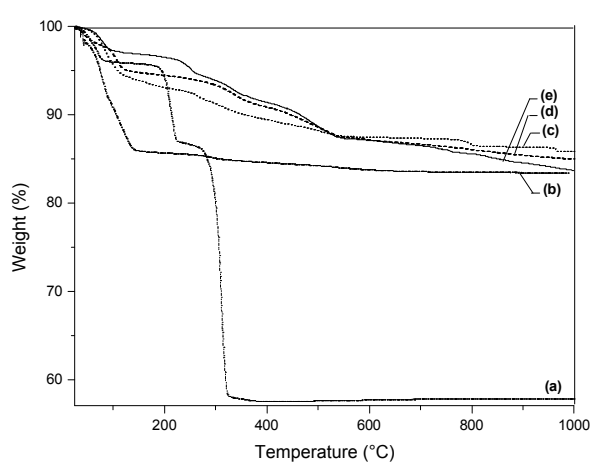

Fig. 2. TGA curves of: (a) $\mathrm{Pt}\left(\mathrm{NH}_{3}\right)_{4} \mathrm{Cl}_{2}$, (b) Na-magadiite, and the $\left[\mathrm{Pt}\left(\mathrm{NH}_{3}\right)_{4}\right]^{2+}$-magadiite samples with different $\mathrm{Pt}$ loadings (c) 13.0 wt.\%, (d) 17.2 wt.\% and (e) 22.2 wt.\%.

prepared by varying the molar ratio of $\mathrm{Na}$ ions (Namagadiite) to $\mathrm{Pt}$ ions in the intercalation reactions, viz, $1: 0.25,1: 1$, and $1: 2$, respectively. The decomposition of the pure $\left[\mathrm{Pt}\left(\mathrm{NH}_{3}\right)_{4}\right] \mathrm{Cl}_{2}$ (curve 'a') complex indicates that there are three distinct ranges of weight losses at $30-150{ }^{\circ} \mathrm{C}, 200$ $240{ }^{\circ} \mathrm{C}$ and $240-340{ }^{\circ} \mathrm{C}$. The first one corresponds to the removal of physisorbed water. The second one corresponds to the elimination of two $\mathrm{NH}_{3}$ ligands. The remaining two $\mathrm{NH}_{3}$ ligands along with two $\mathrm{Cl}$ ligands are desorbed in the third temperature range. The TGA curve of Na-magadiite (curve 'b') shows $14 \%$ weight loss at $30-150{ }^{\circ} \mathrm{C}$, due to the loss of physisorbed water. Comparison of the TGA profile of the pure $\left[\mathrm{Pt}\left(\mathrm{NH}_{3}\right)_{4} \mathrm{Cl}_{2}\right.$ ] complex (curve 'a') with those of the $\left[\mathrm{Pt}\left(\mathrm{NH}_{3}\right)_{4}\right]^{2+}$-magadiite sample (curve 'c') indicates that the decomposition of the $\left[\mathrm{Pt}\left(\mathrm{NH}_{3}\right)_{4}\right]^{2+}$ ions occurs in the higher temperature range of $260-520{ }^{\circ} \mathrm{C}$. It is pertinent to mention here that these values are about $180{ }^{\circ} \mathrm{C}$ higher than those detected in the TGA curve for the pure Pt complex (curve ' $a$ '). Such a shift to the higher temperature region for the decomposition of the $\left[\mathrm{Pt}\left(\mathrm{NH}_{3}\right)_{4}\right]^{2+}$ ions clearly reveals the stabilisation of $\left[\mathrm{Pt}\left(\mathrm{NH}_{3}\right)_{4}\right]^{2+}$ ions within the interlayer spaces of Na-magadiite and not on the external surface of Na-magadiite. Furthermore, the observed small weight (1.5 $\%$ ) loss (curve ' $c$ ') in the temperature range of $600-1000{ }^{\circ} \mathrm{C}$ is probably due to the removal of terminal $\mathrm{OH}$ groups. As can be seen from the curve ' $c$ ' the $\left[\mathrm{Pt}\left(\mathrm{NH}_{3}\right)_{4}\right]^{2+}$ ions can be decomposed completely at $600{ }^{\circ} \mathrm{C}$. Therefore, this temperature of $600{ }^{\circ} \mathrm{C}$ was chosen as the calcination temperature for further studies. As expected, the measured weight loss of $\mathrm{NH}_{3}$ increases with increasing $\left[\mathrm{Pt}\left(\mathrm{NH}_{3}\right)_{4}\right]^{2+}$ loading in the order of $\mathrm{Pt}$ to $\mathrm{Na}$ ratios 1:0.025 (4.4 wt.\%; curve 'c'), 1:1 (5.8 wt.\%; curve 'd') and 1:2 (7.6 wt.\%; curve 'e'). Based on the weight loss of $\mathrm{NH}_{3}$ ligands in the temperature range of $260-520^{\circ} \mathrm{C}$, the $\mathrm{Pt}$ loadings were calculated to be 13.0 , 17.2 and 22.2 wt.\%. In contrast, such a significant uptake of $\left[\mathrm{Pt}\left(\mathrm{NH}_{3}\right)_{4}\right]^{2+}$ ions has not been observed when silica gel (Grace) was used in place of Na-magadiite, under similar intercalation reaction conditions. The amount of Pt loaded on silica gel was considerably lower (1.3 wt.\%; not shown) than the amount of Pt loaded on Na-magadiite (22.2 wt.\%). Such high loading of Pt clearly suggests the high ionexchange capacity and/or the intercalation behaviour of $\mathrm{Na}$ magadiite.

The chemical compositions of the samples prepared from Na-magadiite were also estimated by the ICP analysis. The results are summarized in Table. 1. The Pt loadings were quite high, ranging from 10.2 to $16.4 \%$ in good agreement with the TGA results. It must be noted that no $\mathrm{Na}_{2} \mathrm{O}$ was found in the highly loaded $\mathrm{Pt}$ sample (16.4\%). This result indicates that the maximum ion-exchange capac- 
ity of Na-magadiite is reached under the reaction conditions employed.

Table 1. Chemical compositions of the Pt nanoparticles supported on $\mathrm{SiO}_{2}$ samples prepared from Na-magadiite ${ }^{\mathrm{a}}$.

\begin{tabular}{ccccc}
\hline No & $\begin{array}{c}\mathrm{Na} \\
\text { ratio }^{\mathrm{b}}\end{array}$ & \multicolumn{3}{c}{$\begin{array}{c}\text { Chemical composition } \\
(\text { wt.\%) }\end{array}$} \\
\cline { 3 - 5 } & & $\mathrm{SiO}_{2}$ & $\mathrm{Na}_{2} \mathrm{O}$ & $\mathrm{Pt}$ \\
\hline 1. & $1: 0.025$ & 87.9 & 1.9 & $\begin{array}{c}10.2 \\
(13.0)^{\mathrm{d}}\end{array}$ \\
& & & & \\
2. & $1: 1$ & 83.7 & 0.1 & 16.2 \\
& & & & $(17.2)$ \\
3. & $1: 2$ & 83.6 & 0.0 & $\begin{array}{c}16.4 \\
(22.2)\end{array}$
\end{tabular}

${ }^{\mathrm{a}}$ Chemical composition (wt.\%) of Na-magadiite used in this study was $75.3 \mathrm{SiO}_{2}$. 8.0 Na $\mathrm{Na}_{2} \mathrm{O} 16.7 \mathrm{H}_{2} \mathrm{O}$, ${ }^{\mathrm{b}}$ In the intercalation reactions, ${ }^{\mathrm{c}}$ As determined by ICP analysis, and ${ }^{\mathrm{d}} \mathrm{In}$ parenthesis is the Pt content as determined by TGA analysis.

\subsection{X-ray diffraction (XRD)}

The XRD patterns of the host matrix, Namagadiite, and the $\left[\mathrm{Pt}\left(\mathrm{NH}_{3}\right)_{4}\right]^{2+}$-magadiite samples with different Pt loadings, viz., 13.0, 17.2 and $22.2 \mathrm{wt} . \%$, are shown in Fig. 3 The curve 'a' in Fig. 3 corresponds to the

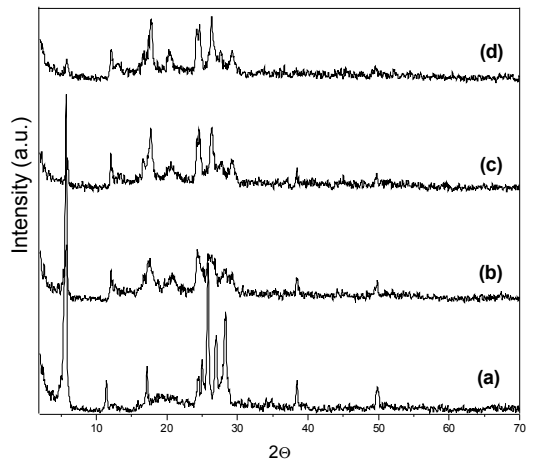

Fig. 3. XRD patterns of: (a) Na-magadiite, and the $\left[\mathrm{Pt}\left(\mathrm{NH}_{3}\right)_{4}\right]^{2+}$-magadiite samples with different Pt loadings (b) 13.0 wt. $\%$, (c) 17.2 wt.\% and (d) 22.2 wt.\%.

XRD pattern of the as-synthesised Na-magadiite used as the host matrix in the intercalation reactions. The recorded XRD pattern of Na-magadiite is typical of magadiite varieties and all the peak positions and relative intensities match well with the reported data [16], indicating that the product is highly crystalline and free from impurities. The basal spacing of the Na-magadiite is $1.54 \mathrm{~nm}$. After the intercalation of $\left[\mathrm{Pt}\left(\mathrm{NH}_{3}\right)_{4}\right]^{2+}$ ions into magadiite, it can be seen from the curves ' $b$ ', ' $c$ ' and ' $d$ ' in Fig. 3 that the reflections of $\left[\mathrm{Pt}\left(\mathrm{NH}_{3}\right)_{4}\right]^{2+}$-magadiite are much broader and weaker in intensity. However, as far as the positions of peaks are con- cerned, the intercalated samples still have the peaks corresponding to Na-magadiite, indicating that the structure was not affected by the introduction of $\left[\mathrm{Pt}\left(\mathrm{NH}_{3}\right)_{4}\right]^{2+}$ ions into Namagadiite. Furthermore, the intercalation of $\left[\mathrm{Pt}\left(\mathrm{NH}_{3}\right)_{4}\right]^{2+}$ ions into magdiite resulted in no significant change in the basal spacing. In fact, in an earlier study on the intercalation of $\mathrm{Co}(\mathrm{sep})^{3+}$ ions into Na-magadiite at $25^{\circ} \mathrm{C}$, it was reported that there was no change in the basal spacing [18]. In addition, when the loading of $\mathrm{Co}(\mathrm{sep})^{3+}$ ions increased, it was also observed that the intensity of the $001\left(2 \theta=5.7^{\circ}\right)$ peak decreased. Similarly, there is a remarkable difference in the intensity of the peak at $2 \theta=5.7^{\circ}$, whose intensity decreases with increasing the Pt content from 13.0 to $22.2 \mathrm{wt} \%$, while the peak position remains unchanged. Taking into account the decrease in the intensity of the peak at $2 \theta=5.7^{\circ}$ with increasing $\mathrm{Pt}$ loading, it is reasonable to assume that $\left[\mathrm{Pt}\left(\mathrm{NH}_{3}\right)_{4}\right]^{2+}$ ions are intercalated within the interlayer spaces of magadiite in agreement with the TGA results.

Upon intercalation of $\left[\mathrm{Pt}\left(\mathrm{NH}_{3}\right)_{4}\right]^{2+}$ ions within the interlayer spaces of magadiite, the broadness of the peaks indicates that there is a slight degradation of the structure of Na-magadiite. In order to find out whether the host matrix, Na-magadiite, is hydrothermally stable under such intercalation reaction conditions, the $\left[\mathrm{Pt}\left(\mathrm{NH}_{3}\right)_{4}\right]^{2+}$-magadiite sample was treated with $\mathrm{NaCl}(2 \mathrm{M})$ solution at room temperature for $48 \mathrm{~h}$. The XRD measurement (not shown) revealed that all the peaks corresponding to Na-magadiite reappeared after treating the $\left[\mathrm{Pt}\left(\mathrm{NH}_{3}\right)_{4}\right]^{2+}$-magadiite sample with $\mathrm{NaCl}$ solution. No significant difference was found in the peak intensities of the $\mathrm{NaCl}$ solution treated $\left[\mathrm{Pt}\left(\mathrm{NH}_{3}\right)_{4}\right]^{2+}$-magadiite sample compared to the host matrix, Na-magadiite. This result indicates that the intercalation of $\left[\mathrm{Pt}\left(\mathrm{NH}_{3}\right)_{4}\right]^{2+}$ ions into the host matrix, Na-magadiite, does not change the original structure of Na-magadiite.

Fig. 4 shows the XRD patterns of the samples of Fig. 3 after calcination at $600^{\circ} \mathrm{C}$ in air for $5 \mathrm{~h}$. As can be

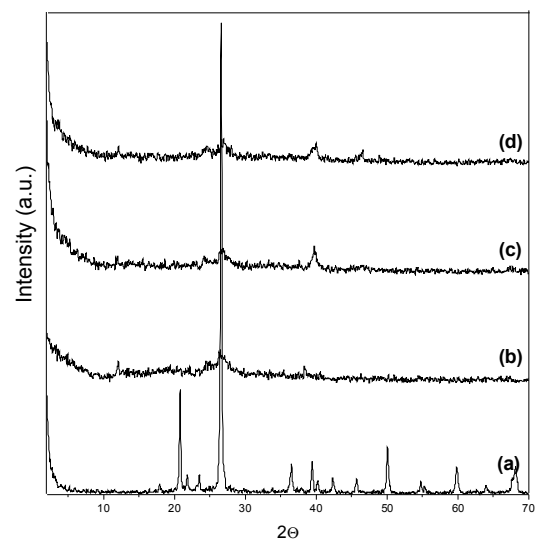

Fig. 4. XRD patterns of the samples of Fig. 3 after calcination at $600{ }^{\circ} \mathrm{C}$ in air: (a) Na-magadiite, and the $\left[\mathrm{Pt}\left(\mathrm{NH}_{3}\right)_{4}\right]^{2+}$ magadiite samples with different Pt loadings (b) 13.0 wt.\%, (c) 17.2 wt. $\%$ and (d) 22.2 wt. $\%$.

seen in curve ' $a$ ' in Fig. 4 there is a considerable change in the XRD pattern of the Na-magadiite compared to the as- 
synthesised Na-magadiite (curve 'a' in Fig. 3). After calcination, Na-magadiite is completely transformed into $\alpha$ quartz $\left(2 \theta=26.61^{\circ}\right)$. It has also been previously reported that Na-magadiite tends to transform into cristobalite and quartz upon calcination at $600{ }^{\circ} \mathrm{C}$ [30]. Nevertheless, after calcination of the intercalated materials, no XRD peaks corresponding to cristobalite and quartz are observed in the XRD patterns (curves ' $b$ ', 'c' and 'd' in Fig. 4). The characteristic magadiite peak at $2 \theta=5.7^{\circ}$ disappears completely, indicating a drastic reduction in the structural ordering. In spite of the disappearance of the peak at $2 \theta=5.7^{\circ}$, some higher order peaks with very low intensity can be seen, which indicates that short range ordering of magadiite is retained even after calcination. Overall, the XRD patterns show only broad features, indicating that the particles are amorphous and are in the nano-size range. It is important to mention that the intercalated samples undergo colour changes from light-yellow to dark-brown during the calcination process, suggesting the formation of $\mathrm{Pt}$ oxides/particles. It is significant to note that the reflections assigned to Pt or its oxides were not detected in the $2 \theta$ range of $30-70^{\circ}$ for the sample with Pt loading of 13.0 wt.\% (curve ' $b$ ' in Fig. 4). This result strongly suggests the absence of large Pt clusters or aggregates indicating the Pt oxides/particles formed during the calcination process are highly dispersed. However, with increasing platinum loading, in addition to the peaks due to the diffraction by magadiite due to short range ordering, two additional peaks at $2 \theta$ values of $39.4^{\circ}$ and $46^{\circ}$ are observed for the samples with Pt loadings of $17.2 \mathrm{wt} . \%$ and 22.2 wt.\% (curves 'c' and 'd' in Fig. 4). These additional peaks corresponding to $\mathrm{Pt}$ oxides/particles are small and very broad. Especially, the peak at $2 \theta=46^{\circ}$ is barely visible. The average platinum crystallite sizes, determined from the peak $\left(2 \theta=39.4^{\circ}\right)$ broadening using the Debye-scherrer equation, are $7.4 \mathrm{~nm}$ and $10.0 \mathrm{~nm}$ for the samples with $\mathrm{Pt}$ loadings of $17.2 \mathrm{wt} . \%$ and $22.2 \mathrm{wt} . \%$, respectively.

\subsection{Transmission electron microscopy ( TEM)}

The stabilisation of $\left[\mathrm{Pt}\left(\mathrm{NH}_{3}\right)_{4}\right]^{2+}$ ions within the host matrix and the formation of Pt nanoparticles after the calcination of the intercalated materials were also confirmed by TEM. The TEM images of the $\left[\mathrm{Pt}\left(\mathrm{NH}_{3}\right)_{4}\right]^{2+}$-magadiite samples with different $\mathrm{Pt}$ loadings are shown in Fig. 5. It can be seen from the TEM images of the samples with Pt loadings of $13.0 \mathrm{wt} . \%$ and $17.2 \mathrm{wt} \%$ (Figs. 5a and 5b), that the $\left[\mathrm{Pt}\left(\mathrm{NH}_{3}\right)_{4}\right]^{2+}$ ions and/or clusters are homogeneously dispersed in the host matrix. The average size of the $\left[\mathrm{Pt}\left(\mathrm{NH}_{3}\right)_{4}\right]^{2+}$ ions and/or clusters is about 2-3 nm, which is slightly greater than the interlayer spaces of Na-magadiite $(1.54 \mathrm{~nm})$. This is in contrast with the XRD results on the intercalated sample where no significant shift in the basal spacing is observed. It is worth noting that there was no significant change in the Pt size when the Pt loading is increased from $13.0 \mathrm{wt} . \%$ to $17.2 \mathrm{wt} . \%$. No large Pt clusters or ill defined aggregates are observed on the surface of the host matrix. These findings thus imply that the interlayer spaces of Na-magadiite $(1.54 \mathrm{~nm})$ play a significant role in enhanc- ing the stabilisation of $\left[\mathrm{Pt}\left(\mathrm{NH}_{3}\right)_{4}\right]^{2+}$ ions during the intercalation reaction.

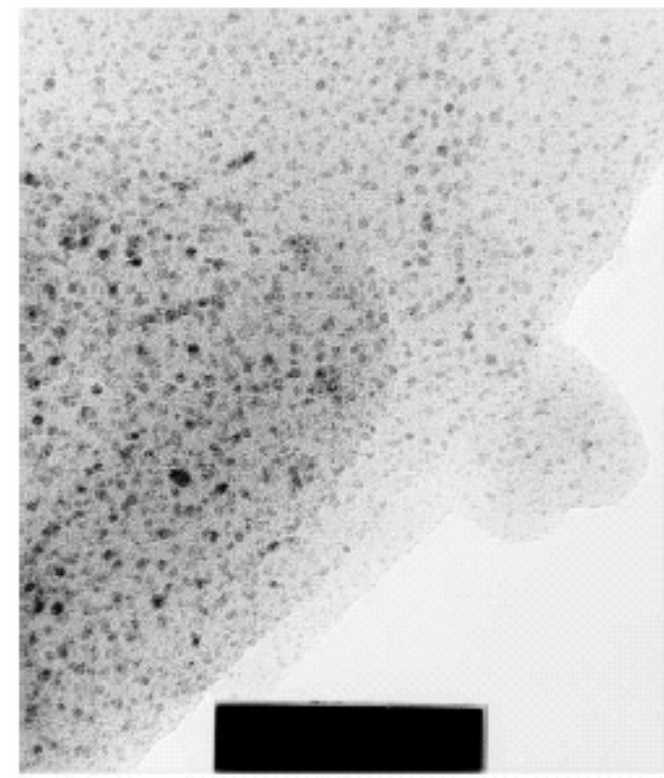

(a)

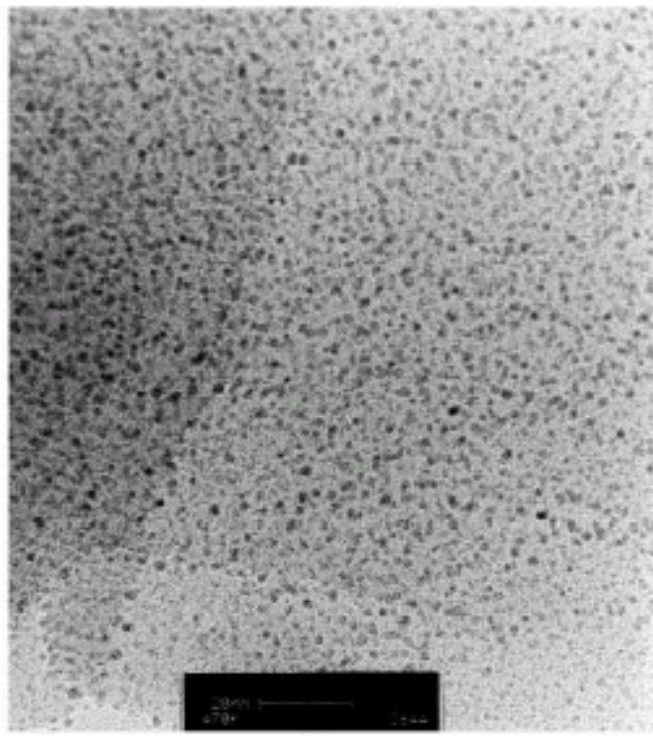

(b)

Fig. 5. TEM images of the $\left[\mathrm{Pt}\left(\mathrm{NH}_{3}\right)_{4}\right]^{2+}$-magadiite samples with different Pt loadings: (a) 13.0 wt.\% and (b) 17.2 wt.\%.

TEM images of the samples of Fig. 5 calcined at $600{ }^{\circ} \mathrm{C}$ in air are shown in Fig. 6. It can be seen from Fig. 6a that some larger Pt nanoparticles (8-12 nm in diameter) are on the surface of the host matrix. However, the Pt nanoparticles are in a highly dispersed state and are uniform in size. Indeed, the average particle size of $\mathrm{Pt}$ is significantly larger than that of the intercalated sample (Fig. 5a), as a result of the agglomeration of Pt nanoparticles during the calcination process. We reported similar findings in our previous study on the intercalation of Na-ilerite with $\left[\mathrm{Pt}\left(\mathrm{NH}_{3}\right)_{4}\right]^{2+}$ ions [28]. We observed the formation of some larger Pt nanoparticles ( $5 \mathrm{~nm}$ in diameter) on the host matrix upon calcination of the 
$\left[\mathrm{Pt}\left(\mathrm{NH}_{3}\right)_{4}\right]^{2+}$-ilerite sample even at the relatively low calcination temperature of $380^{\circ} \mathrm{C}$. Although the diameter of the Pt nanoparticles increases upon calcination, a closer look at

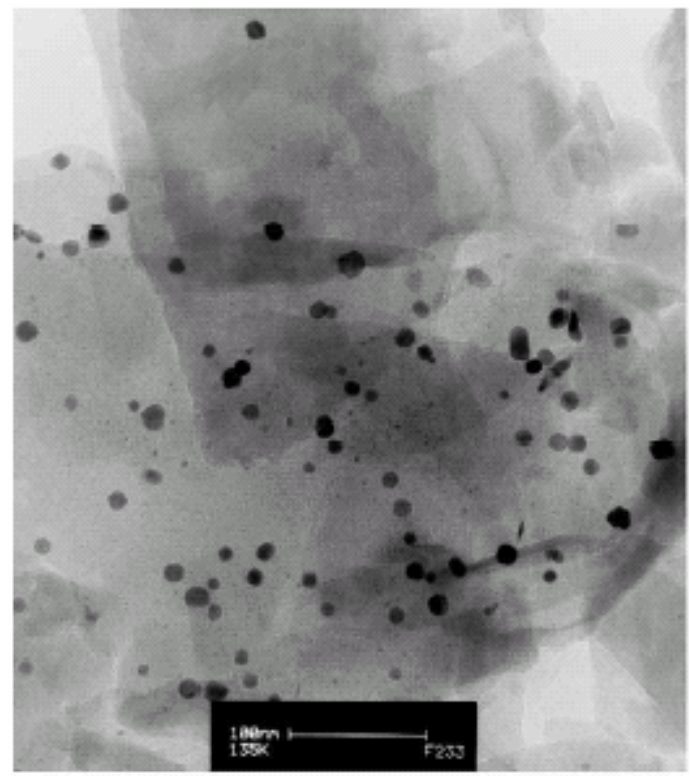

(a)

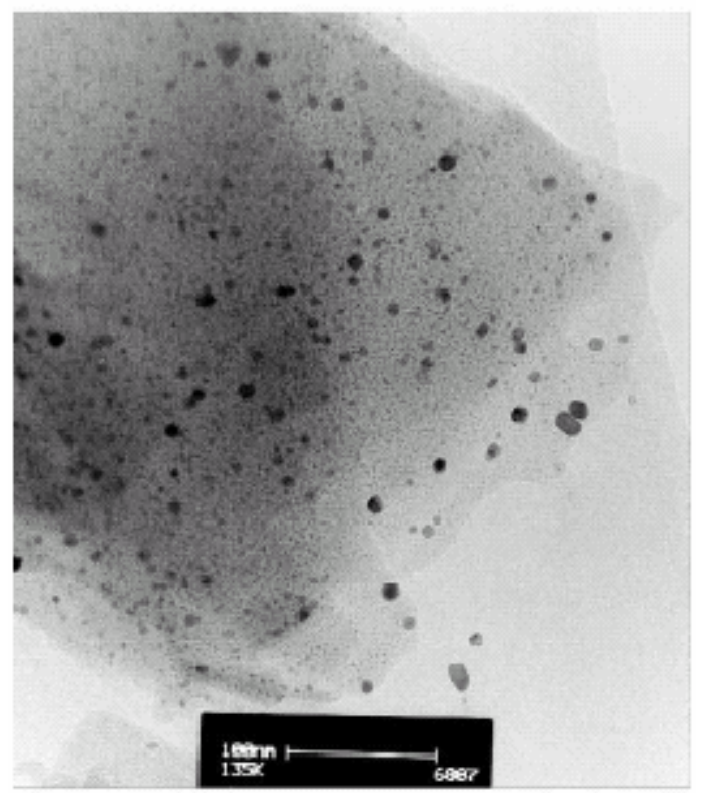

Fig. 6. TEM images of the samples of Fig. 5 calcined at 600 ${ }^{\circ} \mathrm{C}$ in air: (a) 13.0 wt.\% Pt and (b) $17.2 \mathrm{wt.} \% \mathrm{Pt}$.

the Fig. $6 \mathrm{~b}$ indicates that some of the smaller Pt particles are occluded within the host matrix. It is therefore clear that the interlayer spaces of the host matrix magadiite limit the agglomeration of Pt nanoparticles upon calcination. The particle sizes range from $8-12 \mathrm{~nm}$ and 5-12 $\mathrm{nm}$ for the samples with Pt loadings of 13.0 wt. $\%$ and 17.2 wt.\%, respectively.

\section{Conclusions}

The stabilisation of $\left[\mathrm{Pt}\left(\mathrm{NH}_{3}\right)_{4}\right]^{2+}$ ions in a highly dispersed state is achieved in the interlayer spaces of layered sodium silicate magadiite by the intercalation and/or ionexchange method. TGA studies reveal the stabilisation of $\left[\mathrm{Pt}\left(\mathrm{NH}_{3}\right)_{4}\right]^{2+}$ ions within the interlayer spaces of Namagadiite. In comparison to the pure $\left[\mathrm{Pt}\left(\mathrm{NH}_{3}\right)_{4}\right] \mathrm{Cl}_{2}$ complex, the decomposition of the $\left[\mathrm{Pt}\left(\mathrm{NH}_{3}\right)_{4}\right]^{2+}$ ions which are intercalated into magadiite occurs at higher temperatures. The amounts of Pt are higher in magadiite (22.2 wt.\%) compared to silica gel (1.3 wt.\%). Such a high loading of $\mathrm{Pt}$ (22.2 wt.\%) indicates the unique intercalation and/or ionexchange properties of Na-magadiite. XRD measurements on the intercalated samples show the structure of $\mathrm{Na}$ magadiite is not affected by the introduction of $\left[\mathrm{Pt}\left(\mathrm{NH}_{3}\right)_{4}\right]^{2+}$ ions into Na-magadiite, indicating the stability of the host matrix under the intercalation conditions used. The high dispersion of $\left[\mathrm{Pt}\left(\mathrm{NH}_{3}\right)_{4}\right]^{2+}$ ions and/or clusters in the nano size range $(2-3 \mathrm{~nm})$ is confirmed by TEM. Calcination of the $\left[\mathrm{Pt}\left(\mathrm{NH}_{3}\right)_{4}\right]^{2+}$-magadiite samples at $600{ }^{\circ} \mathrm{C}$ in air leads to the formation of $\mathrm{Pt}$ nanoparticles supported on silica. Upon calcination, the size of Pt nanoparticles is increased from 2-3 $\mathrm{nm}$ to $5-12 \mathrm{~nm}$. ICP analysis substantiates the high loading of Pt on silica in agreement with the TGA analysis. We believe that other metal nanoparticles supported on silica can easily be prepared by this intercalation method using Namagadiite as the host matrix.

\section{Acknowledgements}

We thank the Deutsche Forschungsgemeinschaft (Schw 478) and the Fonds der Chemischen Industrie (FCI) for generous financial assistance.

\section{References}

1. U. Ackelid, L. R. Wallenberg and L. G. Peterson, Cata. Lett. 39 (1996) 129.

2. M. Englisch, V. S. Ranade and J. A. Lercher, Appl. Catal. A 163 (1997) 111.

T. Kusakari, K. Tomishige and K. Fujimoto, Appl. Catal. A 224 (2002) 219.

R. Burch and M. D. Coleman, J. Catal. 208 (2002) 435.

S. N. Reifsnyder, M. M. Otten, D. E. Sayers and H. H. Lamb, J. Phys. Chem. B 101 (1997) 4972.

J. W. Yoo, D. Hathcock and M. A. El-Sayed, J. Phys. Chem. A 106 (2002) 2049.

J. Nováková, L. Kubelková, L. Brabec, Z. Bastl, N. Jaeger and G. S. Ekloff, Zeolites 16 (1996) 173.

A. Fukuoka, N. Higashimoto, Y. Sakamoto, S. Inagaki, Y. Fukushima and M. Ichikawa, Microporous Mesoporous Mater. 48 (2001) 171 . 
9. M. Azomoza, T. Lopez, R. Gomez and R. D. Gonzalez, Catal. Today 15 (1992) 547.

10. A. G. Sault, A. Martino, J. S. Kawola and E. Boespflug, J. Catal. 191 (2000) 474;

11. T. Miyao, N. Toyoizumi, S. Okuda, Y. Imai, K. Tajima and S. Naito, Chem. Lett. 10 (1999) 1125.

12. A. Fukuoka, N. Higashimoto, Y. Sakamoto, M. Sasaki, N. Sugimoto, S. Inagaki, Y. Fukushima and M. Ichikawa, Catal. Today 66 (2001) 23

13. M. A. Aramendía, V. Borau, C. Jiménez, J. M. Marinas and F. J. Romero, Chem. Commun. (1999) 873.

14. M. Eswaramoorthy, S. Niwa, M. Toba, H. Shimada, A. Raj and F. Mizukami, Catal. Lett. 71 (2001) 55.

15. C. E-Blaison, E. Sauzéat, M. Pelletier, L. J. Michot, F. Villiéras and B. Humbert, Chem. Mater. 13 (2001) 1480.

16. G. Lagaly, K. Beneke and A. Weiss, Am. Mineral. 60 (1975) 642.

17. L. Mercier, G. A. Facey and C. Detellier, J. Chem. Soc., Chem. Commun. (1994) 2111.

18. J. S. Daily and T. J. Pinnavaia, J. Inclu. Pheno. Mol. Recog. Chem. 13 (1992) 47.

19. N. Mizukami, M. Tsujimura, K. Kuroda and M. Ogawa, Clay and Clay Minerals 50 (2002) 799.

20. M. Ogawa, S. Okutomo and K. Kuroda, J. Am. Chem. Soc. 120 (1998) 7361.

21. K. Isoda and K. Kuroda, Chem. Mater. 12 (2000) 1702.

22. M. Ogawa and Y. Takizawa, J. Phys. Chem. B 103 (1999) 5005.

23. M. Ogawa, T. Ishii, N. Miyamoto and K. Kuroda, Adv. Mater. 13 (2001) 1107; $\quad$ M. Ogawa, J. Mater. Chem. 12 (2002) 3304.

24. G. Pál-Borbély, H. K. Beyer, Y. Kiyozumi and F. Mizukami, Microporous Mesoporous Mater. 11 (1997) 45; G. Pál-Borbély, H. K. Beyer, Y. Kiyozumi and F. Mizukami, Microporous Mesoporous Mater. 22 (1998) 57; T. Selvam and W. Schwieger, Stud. Surf. Sci. Catal. 135 (2001) 411; T. Selvam and W. Schwieger, Stud. Surf. Sci. Catal. 142 (2002) 407.

25. T. Kijima, K: Sakaguchi and K. Ohe, Bull. Chem. Soc. Jpn. 67 (1994) 1281.

26. I. Dékány, L. Turi, G. Galbács, J. H. Fendler, J. Colloid Interface Sci. 213 (1999) 584.

27. Z. Király, I. Dékány, Á. Mastalir, M. Bartók, J. Catal. 161 (1996) 401.

28. W. Schwieger, O. Gravenhorst, T. Selvam, F. Roessner, R. Schlögl, D. Su and G. T. P. Mabande, Colloid Polym Sci. 281 (2003) 584.

29. U. Brenn, W. Schwieger and K. Wuttig, Colloid Polym. Sci. 277 (1999) 394.

$30 . \quad$ S. T. Wong and S. Cheng, Chem. Mater. 5 (1993) 770. 